\title{
Marcin Hundert
}

Uniwersytet Szczeciński

e-mail: marcin.hundert@wzieu.pl

\section{ANALIZA CZYNNIKÓW WPLYWAJĄCYCH NA ORIENTACJE MARKETINGOWĄ TOUROPERATORÓW ${ }^{1}$}

\section{ANALYSIS OF FACTORS AFFECTING MARKETING ORIENTATION OF TOUROPERATORS}

DOI: $10.15611 / \mathrm{pn} .2017 .473 .21$

JEL Classification: Z33

\begin{abstract}
Streszczenie: Pomiar orientacji marketingowej, ze względu na złożoność zachowań przedsiębiorstw turystycznych, nie jest zadaniem łatwym. Zakres działań podejmowanych przez touroperatorów w ramach szeroko rozumianej aktywności marketingowej może przyjmować mniejszy lub większy zasięg, dotyczyć wielu zróżnicowanych aspektów funkcjonowania biura podróży, jak również zależeć od wielu czynników. Czynniki te mogą mieć charakter zarówno wewnętrzny, jak i zewnętrzny. W badaniu przeprowadzonym wśród biur podróży w 11 wybranych krajach europejskich w ramach projektu NCN „Wpływ regulacji na orientację marketingową touroperatorów" zaproponowano 9 potencjalnych obszarów determinujących orientację marketingową. Celem artykułu jest określenie wpływu wybranych obszarów na orientację marketingową touroperatorów przy wykorzystaniu metod statystyczno-ekonometrycznych.
\end{abstract}

Słowa kluczowe: orientacja marketingowa, biura podróży, touroperatorzy, analiza współzależności, analiza regresji.

Summary: Measurement of marketing orientation due to the complexity of the behavior of tourism businesses is not an easy task. Both the number and range of activities undertaken by companies in the context of the wider marketing activity can have a greater or lesser extent, affect many different aspects and depend on many factors. In the survey of travel agencies in eleven selected European countries, as part of NCN project "Impact of regulation on marketing orientation of tour operators", 9 potential areas were suggested for determining the orientation of marketing. The aim of this article is to determine the effect of selected areas on a marketing orientation of tour operators using the statistical and econometric methods.

Keywords: marketing orientation, travel agency, touroperators, interdependencies analisys, regression analisys.

${ }^{1}$ Artykuł został sfinansowany ze środków Narodowego Centrum Nauki przyznanych na podstawie decyzji numer DEC-2013/09/B/HS4/01286. 


\section{Wstęp}

Każde przedsiębiorstwo bez względu na profil działalności musi w celu osiągania zysku sięgać i dostosowywać do własnych potrzeb wybrane metody marketingu. Jak piszą Kotler i Keller [2012, s. 5], marketing zdefiniować można jako zasadę ,zaspokajać potrzeby, osiągając zysk". Kierowanie się tą zasadą jest szczególnie wskazane w działalności usługowej, do jakiej należy działalność touroperatorów. W literaturze zorientowanie na klienta nazywa się orientacją marketingową lub orientacją rynkową przedsiębiorstwa. Na przykład według J. Penca [2007, s. 52] przedsiębiorstwo stosujące orientację marketingową dąży do stworzenia długookresowych więzi między klientem a przedsiębiorstwem. Natomiast zorientowane rynkowo działa w sposób polegający na podejmowaniu działań zmierzających do zrozumienia istoty potrzeb nabywców oraz zaspokojenia ich w sposób lepszy, niż czynią to konkurenci [Garbarski (red.) 2011, s. 19]. W przypadku touroperatorów wyją̧tkowo istotnym elementem działań marketingowych są ludzie. Działania te dotyczyć powinny zarówno klientów, jak i pracowników firmy. Wyraz tej koncepcji dał A. Panasiuk, podając, iż marketingowo zorientowane przedsiębiorstwo powinno skutecznie kształtować swoje działania w zakresie marketingu zewnętrznego, marketingu wewnętrznego i marketingu interakcyjnego. Przy czym za marketing wewnętrzny uważa te działania przedsiębiorstwa, które mają na celu przeszkolenie i motywowanie pracowników do lepszej obsługi klientów. Natomiast w przypadku tego ostatniego twierdzi, że „marketing interakcyjny sprowadza się do oddziaływania na wszystkich pracowników firmy, mającego kształtować pożądane prousługowe i projakościowe postawy w relacjach między usługobiorcą a usługodawcą" [Panasiuk (red.) 2005, s. 21-22].

Orientację marketingową rozumieć należy jako rzeczywistą implementację koncepcji marketingowej w działalności przedsiębiorstwa, umożliwiającą osiągnięcie długoterminowej przewagi konkurencyjnej za pomocą analizy rynku, otoczenia, konkurencji oraz zaprogramowanych działań z wykorzystaniem uzyskanych informacji [Lado i in. 1998, s. 23-39]. Pomiar orientacji marketingowej możliwy jest dzięki jej właściwemu zdefiniowaniu, przy wykorzystaniu odpowiednich metod i technik zarówno jakościowych, jak i ilościowych. Podejście ilościowe do orientacji marketingowej pojawiło się w latach 90. [Kohli, Jaworski 1990; Kohli i in. 1993; Narver, Slater 1990]. Pomiar odbywał się wówczas za pośrednictwem ankiet skierowanych do przedsiębiorstw, w których ich kierownicy oceniali poszczególne elementy na 7- lub 5-stopniowej skali Likerta (od 15 do 32 pozycji), pogrupowanych w odpowiednie obszary. Orientacja marketingowa szacowana była jako średnia (lub średnia ważona) z odpowiedzi respondentów na poszczególne pytania. W nawiązaniu do badań B.J. Jaworskiego, A.K. Kohliego i A. Kumara celem artykułu jest określenie wpływu zaproponowanych obszarów na orientację marketingową touroperatorów w 11 wybranych krajach europejskich² przy użyciu wybranych metod ilościowych.

\footnotetext{
${ }^{2}$ Badaniu poddano następujące kraje: Polska, Niemcy, Szwecja, Estonia, Luksemburg, Holandia, Wielka Brytania, Szwajcaria, Finlandia, Dania i Irlandia
} 


\section{Metodyka badania}

Koncepcja pomiaru orientacji marketingowej, jak i wykorzystanych metod badawczych została zaczerpnięta z badań Jaworskiego i Kohliego. Przedstawione w artykule wyniki opierają się na danych otrzymanych w ramach projektu NCN „Wpływ regulacji na orientację marketingową touroperatorów"3. Etap gromadzenia danych przeprowadzono w drugim i trzecim kwartale 2016 r., a użytym narzędziem badawczym był formularz ankietowy. W celu określenia orientacji marketingowej zaproponowano do formularza ankietowego zestaw kilkudziesięciu (dokładnie 63) stwierdzeń, pogrupowanych w następujące obszary tematyczne:

1. Orientacja biura podróży na potrzeby klienta.

2. Komunikacja w biurze podróży - stwierdzenia z tego obszaru tematycznego dotyczyły komunikacji wewnętrznej biura podróży pomiędzy pracownikami/działami.

3. Reakcja biura podróży na zmiany w otoczeniu.

4. Implementacje (wdrażanie zmian adekwatnie do reakcji rynku).

5. Kierownictwo biura podróży - ten obszar tematyczny zawierał stwierdzenia badające zachowanie kierownictwa biura podróży.

6. Orientacja na system nagród - stwierdzenia z tego obszaru badały ocenę systemu nagród pracowników.

7. Utożsamianie się pracowników z biurem podróży.

8. Turbulencje rynkowe - pod tą nazwą kryły się stwierdzenia odnoszące się do dynamiki rynku touroperatorskiego.

9. Intensywność konkurencji - w tym obszarze badano zachowania na działania konkurencji.

Następnie w celu sprawdzenia merytoryczności i adekwatności przyjętych stwierdzeń oraz obszarów tematycznych posłużono się metodą delficką. Natomiast do zbadania rzetelności pomiaru wykorzystano współczynnik alfa Cronbacha ${ }^{4}$. Dodatkową weryfikację formularza stanowiło badanie pilotażowe.

Ostatecznie do formularza, który przedstawiono respondentom, weszły 44 stwierdzenia pogrupowane w wymienione wyżej 9 obszarów tematycznych. Kwestionariusz ankietowy został skonstruowany w trzech wersjach językowych - po polsku, angielsku i niemiecku, a jego rozpowszechnianie odbywało się przede wszystkim przez formularz ankietowy on-line udostępniany przez Google. Założono uzyskanie 4000 adresów touroperatorów z określonych w projekcie 11 krajów oraz zwrotność

\footnotetext{
${ }^{3}$ Wybór krajów zdeterminowany był wykonaną na wcześniejszym etapie badań analizą regulacji rynku touroperatorów w ramach grantu badawczego „Wpływ regulacji na orientację marketingową touroperatorów" pod kier. A. Panasiuka, UMO-2013/09/B/HS4/01286.

${ }^{4}$ Obecnie najczęściej stosowaną metodą do szacowania rzetelności jest wzór opracowany przez Cronbacha [1951, s. 297-334]. Współczynnik ten przyjął wartość 0,86, co zgodnie z kryterium Nunnally’ego [Nunnally 1978] oznacza, że formularz został poprawnie zbudowany.
} 
na poziomie $10 \%$. Jednakże udało się ustalić i zgromadzić 3828 adresów, do których rozesłano prośbę o wypełnienie ankiety. Ze względu na trudności z otrzymywaniem wypełnionych ankiet - przedstawiciele touroperatorów (pracownicy, kierownicy biur, właściciele) wskazywali na brak czasu, natłok obowiązków lub w ogóle nie odpowiadali na prośby o wypełnienie ankiety - ponowiono wysyłkę ankiet (wysłano ponad 6200 wiadomości e-mail). Ostatecznie zdecydowano się na wyjazdy do badanych krajów w celu przeprowadzenia wywiadów osobistych. Udało się uzyskać łącznie 380 prawidłowo wypełnionych ankiet, w tym 204 formularze z Polski oraz $176 \mathrm{z}$ pozostałych krajów europejskich objętych badaniem.

W ramach każdego obszaru tematycznego respondenci oceniali stwierdzenia wyskalowane na 5-stopniowej skali Likerta, gdzie 1 oznaczało „zdecydowanie nie”, a 5 ,zdecydowanie tak”. Przy tak zbudowanym formularzu, na podstawie koncepcji B.J. Jaworskiego i A.K. Kohliego, orientację marketingową touroperatorów oraz oceny poszczególnych obszarów uzyskano jako nieważoną sumę ze wskazań dla odpowiednich stwierdzeń. W artykule przyjęto [za: Jaworski, Kohli 1993], że orientację marketingową tworzą wyłącznie obszary od 1 do 4 .

Ponieważ biuro podróży jest miejscem olbrzymiej liczby wewnętrznych i zewnętrznych akcji i interakcji, które składają się na procesy masowe ${ }^{6}$, możliwe jest przy użyciu odpowiednich metod ilościowych wykrycie prawidłowości występujących zarówno wewnątrz biur podróży, jak i w ich otoczeniu. Obserwując pozorny chaos występujący w wydarzeniach ekonomicznych, można zauważyć, że pewne zdarzenia pojawiają się często w wyniku podejmowanych działań lub też pewne działania podejmowane są z powodu zaistniałych zdarzeń7 ${ }^{7}$ O występowaniu prawidłowości i ich wadze O. Lange pisze: „Proces gospodarczy jest kompleksem stale powtarzających się działań ludzkich. W określonych warunkach, wynikających z danego rozwoju historycznego społeczeństwa, działania te powtarzają się w określony sposób, czyli odznaczają się prawidłowością. Prawidłowość tę można rozłożyć na pewne elementy stale powtarzających się związków; związki takie określamy mianem praw ekonomicznych" [Pawłowski 1978, s. 74]. Według J. Hozera obserwowane prawidłowości nie są wprawdzie tak powszechne i stałe, jak w przypadku nauk izomorficznych (fizyka, chemia), niemniej fakt ich występowania zezwala na budowę teorii funkcjonowania systemów gospodarczych (przedsiębiorstw, gospodarstw domowych) na rynku za pomocą aparatu ilościowego [Hozer 1993, s. 9].

Do wykrycia prawidłowości występujących pomiędzy zmiennymi, czyli orientacją marketingową touroperatorów a pozostałymi pięcioma obszarami tematycznymi, nazywanymi w dalszej części czynnikami, posłużono się zestawem podstawowych

\footnotetext{
${ }^{5}$ Jako minimalną liczebność próby przyjęto 270 formularzy, przy założeniach: prawdopodobieństwo $90 \%$, błąd pomiaru $5 \%$.

${ }^{6}$ Procesy masowe, czyli zachodzenie dużej liczby zdarzeń, są źródłem powstawania prawidłowości statystycznych.

${ }^{7} \mathrm{~W}$ takim ujęciu mówi się o związkach przyczynowych, związkach celowych i współistnienia [Hozer 1993, Hozer (red.) 1997].
} 
miar statystyki opisowej i matematycznej oraz modelem regresji wielorakiej zaproponowanymi przez Jaworskiego i Kohliego. Miary statystyki opisowej obejmowały parametry tendencji centralnej, takie jak: wartość średnia, odchylenie standardowe, współczynnik zmienności, kwartyl pierwszy i trzeci oraz współczynnik korelacji liniowej Pearsona, natomiast z zakresu modelowania ekonometrycznego - funkcję regresji wielorakiej. Ponieważ wybrane parametry statystyki opisowej należą do powszechnie stosowanych i prostych, nie omówiono ich szczegółowo ${ }^{8}$. W dalszej części krótko scharakteryzowano sposób uzyskiwania funkcji regresji wielorakiej.

Przy poszukiwaniu istotnych związków pomiędzy zjawiskiem ekonomicznym a determinującymi je czynnikami warto posłużyć się modelem regresji liniowej. Najczęściej stosowaną metodą szacowania parametrów strukturalnych takiego modelu jest klasyczna metoda najmniejszych kwadratów (KMNK)9. Popularność tej metody związana jest z faktem, że w wyniku jej stosowania uzyskuje się tzw. estymatory BLUE ${ }^{10}$, czyli zgodne, nieobciążone i najefektywniejsze, nawet bez założenia normalności rozkładu rozpatrywanych zmiennych. Najczęściej wykorzystywanym wzorem na estymatory parametrów jest wzór macierzowy:

$$
\mathrm{A}=\left(X^{T} X\right)^{-1} X^{T} Y,
$$

gdzie: A - wektor ocen parametrów strukturalnych, $Y$ - wektor obserwacji zmiennej objaśnianej, $X$ - macierz obserwacji zmiennych objaśniających.

a w wyniku estymacji otrzymamy model liniowy:

$$
\hat{Y}_{t}=a_{0}+a_{1} X_{1 t}+a_{2} X_{2 t}+\ldots+a_{k} X_{k t},
$$

gdzie: $\hat{Y}_{t}-$ wartość teoretyczna zmiennej objaśnianej, $X_{k t}-$ zmienne objaśniające, $a_{k}$ - estymatory parametrów strukturalnych modelu.

Istotną częścią procesu budowy modelu jest jego weryfikacja. Weryfikacja obejmuje tzw. weryfikację merytoryczną i statystyczną. Weryfikacja merytoryczna sprowadza się do oceny znaków stojących przy parametrach strukturalnych poszczególnych zmiennych. Ocena ta ma na celu sprawdzenie zgodności znaków ze spodziewaną relacją między daną zmienną niezależną a zmienną objaśnianą, wynikającą z teorii ekonomii lub z naszych oczekiwań. Weryfikacja statystyczna natomiast polega na ocenie jakości modelu przy użyciu odpowiednich parametrów i testów statystycznych. Niestety, nie istnieją jednoznaczne kryteria oceny otrzymy-

\footnotetext{
${ }^{8}$ Metody statystyki opisowej można znaleźć w wielu podręcznikach, m.in.: [Hozer 1998; Dolny, Sienkiewicz 2000; Hundert i in. 2006, Ostasiewicz i in. 2011, Sobczyk 2016].

${ }^{9}$ Obok KMNK stosowane są także inne metody estymacji, takie jak: uogólniona metoda najmniejszych kwadratów, metody różniczki zupełnej, metoda największej wiarygodności oraz metody estymacji modeli nieliniowych

${ }^{10}$ Koncepcja BLUE - Best, Linear, Unbiast and Effective Estimators, czyli zgodne nieobciążone i najefektywniejsze estymatory, co wynika z twierdzenia Gaussa-Markova.
} 
wanych rezultatów, pomimo podejmowanych prób ich ujednolicenia. Jedynym pewnikiem w tej materii jest fakt, iż na pewno istnieją modele lepsze i gorsze. Ta swoista dowolność w podchodzeniu do kryteriów oceny modeli powoduje, że weryfikacja należy do najtrudniejszych etapów budowy modelu.

\section{Analiza wpływu wybranych obszarów na orientację marketingową touroperatorów ${ }^{11}$}

Jak wspomniano wcześniej, zarówno orientację marketingową (OM), jak i wartości dla poszczególnych obszarów uzyskano jako nieważoną sumę ocen ze stwierdzeń należących do poszczególnych obszarów. Stwierdzenia te zostały wyskalowane na 5 -stopniowej skali Likerta, gdzie 5 oznaczało całkowicie się zgadzam. Jednakże ze względu na fakt, iż dla niektórych stwierdzeń oczekiwaną odpowiedzią było 1 , czyli całkowicie się nie zgadzam, zmienne te przed zsumowaniem przekodowano, zamieniając wartości na skali. Dzięki temu zabiegowi oczekiwanej odpowiedzi zawsze odpowiadała wartość 5. Dopiero tak przygotowane dane poddano analizie. We wszystkich testach statystycznych oraz estymacji przedziałowej przyjęto poziom istotności 0,05 .

Analizę rozpoczęto od obliczenia zestawu miar opisowych zarówno dla zmiennej Orientacja Marketingowa, jak i dla pozostałych obszarów, których wpływ na OM postanowiono określić (zob. tab. 1).

Przeciętny poziom orientacji marketingowej dla badanych państw kształtował się na poziomie $92,9 \mathrm{pkt}$, przy czym dla otrzymanego przedziału ufności na 95\% OMT mieściłaby się w przedziale od 91,8 do 94,1. Można więc przyjąć, że rozpiętość tego przedziału jest zadowalająca. Zróżnicowanie krajów pod względem orientacji, przy współczynniku zmienności na poziomie 12,1\%, można uznać za nieznaczne. W przypadku obszarów, których wpływ na OM zostanie poddany badaniu w dalszej części, zauważono, że najwyższą średnią spośród nich ma Obszar 7: Utożsamianie się pracowników z biurem podróży, natomiast najniższą Obszar 9: Intensywność konkurencji. Wskazywać by to mogło, że w biurach podróży większą wagę przykłada się do relacji z pracownikami i postrzegania przez nich miejsca pracy niż do działań konkurencji. Analizując zaś współczynniki zmienności, można zauważyć, że największą zmiennością odpowiedzi (wsp. zm. 35,88\%) charakteryzuje się Obszar 6: Orientacja na system nagród. Pozostałe cztery obszary mają natomiast zmienność na zbliżonym poziomie. Większe zróżnicowanie odpowiedzi w Obszarze 6 prawdopodobnie wynika ze znacząco różnego sposobu kształtowania systemu wynagradzania pracowników w zależności od kraju.

${ }^{11}$ Wszystkich obliczeń dokonano w programie Statistica 12 firmy Statsoft. 
Tabela 1. Wybrane statystyki dla Orientacji Marketingowej Touroperatorów i pozostałych obszarów

\begin{tabular}{|l|c|c|c|c|c|c|c|}
\hline \multirow{2}{*}{ Zmienna } & \multicolumn{7}{|c|}{ Statystyki opisowe } \\
\cline { 2 - 8 } & średnia & $\begin{array}{c}\text { ufność* } \\
-95,000 \%\end{array}$ & $\begin{array}{c}\text { ufność* } \\
95,000 \%\end{array}$ & minimum & maksimum & $\begin{array}{c}\text { odch. } \\
\text { std.* }\end{array}$ & $\begin{array}{c}\text { wsp. } \\
\text { zm.* }\end{array}$ \\
\hline $\begin{array}{l}\text { Orientacja } \\
\text { Marketingowa } \\
\text { Touroperatorów }\end{array}$ & 92,979 & 91,843 & 94,115 & 47,0 & 114,0 & 11,266 & 12,117 \\
\hline $\begin{array}{l}\text { Obszar 5: } \\
\text { Kierownictwo biura } \\
\text { podróży }\end{array}$ & 12,526 & 12,294 & 12,759 & 4,0 & 15,0 & 2,306 & 18,406 \\
\hline $\begin{array}{l}\text { Obszar 6: Orientacja } \\
\text { na system nagród }\end{array}$ & 12,411 & 11,962 & 12,859 & 4,0 & 20,0 & 4,448 & 35,844 \\
\hline $\begin{array}{l}\text { Obszar 7: } \\
\text { Utożsamianie } \\
\text { się pracowników } \\
\text { z biurem podróży }\end{array}$ & 24,189 & 23,749 & 24,630 & 11,0 & 30,0 & 4,364 & 18,042 \\
\hline $\begin{array}{l}\text { Obszar 8: Turbulencje } \\
\text { rynkowe }\end{array}$ & 14,063 & 13,828 & 14,298 & 7,0 & 20,0 & 2,333 & 16,588 \\
\hline $\begin{array}{l}\text { Obszar 9: } \\
\text { Intensywność } \\
\text { konkurencji }\end{array}$ & 10,653 & 10,445 & 10,860 & 6,0 & 15,0 & 2,059 & 19,325 \\
\hline
\end{tabular}

* Ufność to dolna i górna granica przedziału ufności dla wartości średniej, Odch.std to odchylenie standardowe, natomiast Wsp.zm. to współczynnik zmienności.

Źródło: opracowanie własne.

Tabela 2. Współczynniki korelacji liniowej Pearsona pomiędzy OMT i obszarami

\begin{tabular}{|l|c|c|c|c|c|c|}
\hline \multirow{2}{*}{ Zmienna } & \multicolumn{6}{|c|}{ Współczynniki korelacji liniowej Pearsona* } \\
\cline { 2 - 7 } & OMT & $\begin{array}{c}\text { obszar } \\
5\end{array}$ & $\begin{array}{c}\text { obszar } \\
6\end{array}$ & $\begin{array}{c}\text { obszar } \\
7\end{array}$ & $\begin{array}{c}\text { obszar } \\
8\end{array}$ & $\begin{array}{c}\text { obszar } \\
9\end{array}$ \\
\hline $\begin{array}{l}\text { Orientacja Marketingowa } \\
\text { Touroperatorów }\end{array}$ & 1,000 & & & & & \\
\hline Obszar 5: Kierownictwo biura podróży & $0,560 * *$ & 1,000 & & & & \\
\hline Obszar 6: Orientacja na system nagród & $0,523 * *$ & $0,420 * *$ & 1,000 & & & \\
\hline $\begin{array}{l}\text { Obszar 7: Utożsamianie się } \\
\text { pracowników z biurem podróży }\end{array}$ & $0,264 * *$ & $0,282 * *$ & $0,242 * *$ & 1,000 & & \\
\hline Obszar 8: Turbulencje rynkowe & $0,267 * *$ & $0,198^{* *}$ & $-0,001$ & $-0,154 * *$ & 1,000 & \\
\hline Obszar 9: Intensywność konkurencji & $0,332 * *$ & $0,145^{* *}$ & $0,194 * *$ & $-0,115^{* * *}$ & $0,361 * *$ & 1,000 \\
\hline
\end{tabular}

* Brak wartości nad główną przekątną tabeli wynika z symetryczności współczynnika korelacji liniowej Pearsona; ** współczynniki korelacji istotne statystycznie.

Źródło: opracowanie własne. 
W celu określenia związków pomiędzy obszarami od 5 do 9 a orientacją marketingową, najpierw obliczono współczynniki korelacji liniowej Pearsona pomiędzy OMT a wymienionymi obszarami [za: Jaworski, Kohli 1993]. Współczynniki przedstawia tabela 2.

Podejmując próbę określenia związków poszczególnych obszarów z orientacją marketingową, należy stwierdzić, że wszystkie analizowane obszary istotnie i dodatnio wpływają na OMT. Najsilniejszy wpływ na orientację marketingową wykazują Obszar 5: Kierownictwo biura podróży oraz Obszar 6: Orientacja na system nagród. Natomiast najsłabszy wpływ na orientację marketingową ma to, czy pracownicy utożsamiają się z biurem podróży, a także zmiany na rynku usług touroperatorskich (Turbulencje rynkowe). Nie wykazano związku pomiędzy Obszarem 6: Orientacja na system nagród a Obszarem 8: Turbulencje rynkowe. Należałoby się zastanowić, czy kierownictwo biura nie mogłoby wykorzystywać systemu nagród, jako czynnika stymulującego orientację marketingową $\mathrm{w}$ odpowiedzi na zmiany na rynku touroperatorów. Brak związku między Obszarem 6 i 7 sugeruje, że się tak nie dzieje. Natomiast najsilniejszy związek pomiędzy obszarami 5 i 6: Kierownictwo biura podróży a Orientacja na system nagród wydaje się zgodny z oczekiwaniami. Zachowanie kierownictwa ma wpływ na ocenę systemu nagród przez pracowników.

Ciekawą relację można zaobserwować pomiędzy Utożsamianiem się pracowników z biurem podróży (Obszar 7) a Turbulencjami rynkowymi (Obszar 8) oraz Intensywnością konkurencji (Obszar 9). Pomiędzy wymienionymi zmiennymi występuje zależność ujemna. Oznaczałoby to, że wzrost turbulencji rynkowych oraz intensywności konkurencji wpływa na spadek utożsamiania się pracowników z biurem podróży. Może to wskazywać na fakt, iż kierownictwo nie reaguje w odpowiedni sposób na te zmiany, przez co pracownicy tracą zaufanie do biura.

Następnie w celu określenia wpływu poszczególnych obszarów na orientację marketingową zbudowany został model regresji wielorakiej, w którym OMT odgrywało rolę zmiennej objaśnianej, natomiast obszary od 5 do 9 były zmiennymi objaśniającymi. Wyniki estymacji zamieszczono w tabeli 3.

Oszacowany model OMT na tle poszczególnych obszarów ma postać:

$$
\hat{Y}_{t}=32,7965+1,6132 X_{1 t}+0,7997 X_{2 t}+0,3613 X_{3 t}+0,7621 X_{4 t}+0,9945 X_{5 t} \text {, }
$$

gdzie: $\hat{Y}_{t}$ - wartość teoretyczna OMT, $X_{1 t}, X_{2 t}, X_{3 t}, X_{4 t}$ - to zmienne odpowiadające odpowiednio obszarom $5,6,7,8$ i 9 .

Uzyskane wyniki potwierdzają, iż wszystkie obszary mają dodatni i statystycznie istotny ${ }^{12}$ wpływ na orientację marketingową touroperatorów. Dzięki wartościom parametrów strukturalnych możliwe jest określenie kierunku, a także wskazanie, które spośród obszarów mają większy, a które mniejszy wpływ na OMT (są ważniejsze/mniej ważne dla OMT).

\footnotetext{
${ }^{12}$ Istotność badano dla $\alpha=0,05$.
} 
Tabela 3. Wyniki obliczeń dla modelowania OMT względem obszarów

\begin{tabular}{|l|c|c|}
\hline \multirow{2}{*}{\multicolumn{1}{|c|}{$\mathrm{N}=380$}} & $\begin{array}{c}\text { Podsumowanie regresji zmiennej } \\
\text { zależnej: OMT } \\
\mathrm{R}^{2}=0,4895^{*} \text { Błąd std. } \\
\text { estymacji**: 8,1028 }\end{array}$ \\
\cline { 2 - 3 } & $\mathrm{b}$ & $\mathrm{B}$. std. \\
\hline W. wolny & 32,7965 & 4,1089 \\
\hline Obszar 5: Kierownictwo biura podróży & 1,6132 & 0,2105 \\
\hline Obszar 6: Orientacja na system nagród & 0,7997 & 0,1067 \\
\hline Obszar 7: Utożsamianie się pracowników z biurem podróży & 0,3613 & 0,1035 \\
\hline Obszar 8: Turbulencje rynkowe & 0,7621 & 0,1986 \\
\hline Obszar 9: Intensywność konkurencji & 0,9945 & 0,2234 \\
\hline
\end{tabular}

* Dopasowanie modelu; ** błąd modelu.

Źródło: opracowanie własne.

I tak, obszary można uporządkować następująco ze względu na ich wpływ na orientację marketingową: Obszar 5, Obszar 9, Obszar 6, Obszar 8 i na końcu Obszar 7. Wpływ na orientację touroperatora zależy więc od odpowiedniego podejścia do tego zagadnienia przez kadrę kierowniczą (Kierownictwo biura podróży; 1,6132) i jej otwartości na innowacyjne strategie marketingowe. Wzrost orientacji wymuszany jest również w znaczny sposób przez intensywność działań konkurencji $(0,9945)$. Touroperator może wpływać na orientację marketingową także poprzez odpowiednie sposoby motywowania pracowników, które związane będą z reagowaniem na potrzeby klienta (Orientacja na system nagród; 0,7997). Wynika to z silnego zorientowania pracowników na system nagród. Najmniejszy wpływ na orientację marketingową ma utożsamianie się pracowników z biurem podróży (Obszar 7; 0,3613). Można stąd wyciągnąć wniosek, iż osobiste odczucia pracowników co do przedsiębiorstwa z punktu widzenia OMT nie są tak ważne, jeśli kierownictwo odpowiednio orientuje tych pracowników, a system nagród premiuje za otwarcie na potrzeby klientów.

\section{Zakończenie}

Problematykę orientacji marketingowej touroperatorów oraz czynnikami wywierającymi na nią wpływ należy traktować jako badanie wstępne. Badania tego rodzaju należałoby powtórzyć na większej próbie zarówno w Polsce, jak i innych krajach europejskich, a ich wyniki do siebie porównać. Niemniej dzięki przeprowadzonym badaniom stwierdzono, że najistotniejszym czynnikiem z punktu widzenia orientacji marketingowej jest kadra kierownicza. To przyjęta przez kierownictwo strategia i wiedza o mechanizmach funkcjonowania rynku oraz zachowań konsumentów, 
a także adekwatna i szybka reakcja na bodźce zewnętrzne ma decydujący wpływ na orientację marketingową. Zachowania kadry kierowniczej są także wzorcem i stanowią motywację dla pozostałych pracowników biura. Nie bez znaczenia jest również stworzenie „dobrego” systemu wynagradzania pracowników, co wynika z ich silnego zorientowania na system nagród. Pewnym zaskoczeniem jest natomiast niewielki wpływ utożsamiania się pracowników z biurem podróży na orientację marketingową touroperatorów. Możliwe jest, że czynnik ten jest przeceniany, a pracownik powinien wyłącznie profesjonalnie i należycie podchodzić do swoich obowiązków służbowych.

\section{Literatura}

Cronbach L.J., 1951, Coefficient alpha and the internal structure of tests, Psychometrica, vol. 16.

Dolny E., Sienkiewicz K., 2000, Podstawy statystyki, Wydawnictwo Toruńskiej Szkoły Zarządzania, Torun.

Garbarski L. (red.), 2011, Marketing. Kluczowe pojęcia i praktyczne zastosowania, PWE, Warszawa. Hozer J., 1993, Mikroekonometria. Analizy, diagnozy, prognozy, PWE, Warszawa.

Hozer J., 1998, Statystyka. Opis statystyczny, Wydawnictwo Uniwersytetu Szczecińskiego, Szczecin. Hozer J. (red.), 1997, Ekonometria, Akcydens, Szczecin.

Hundert M. i in., 2006, Wybrane zagadnienia ze Statystyki, Economicus, Szczecin.

Jaworski B., Kohli A., 1993, Market orientation: Antecendents and Consequences, Journal of Marketing, vol. 57 , no. 3 .

Kohli A., Jaworski B., 1990, Market Orientation: The Construct, Research Propositions, and Managerial Implications, The Journal of Marketing, vol. 54, no. 2.

Kohli A., Jaworski B., Kumar A., 1993, MARKOR: A measure of market Orientation, Journal of Marketing Research, vol. 30, no. 4.

Kotler Ph., Keller K.L., 2012, Marketing, Dom Wydawniczy Rebis, Poznań.

Lado N., Maydeu-Olivares A., Rivera J., 1998, Measuring market orientation in several populations. A structural equations model, European Journal of Marketing, vol. 32.

Narver J., Slater S., 1990, The effect of a marketing orientation on business profitability, Journal of Marketing, vol. 54, no. 4.

Nunnaly J., 1978, Psychometric Theory, New York, McGraw-Hill.

Ostasiewicz S., Rusnak Z., Siedlecka U., 2011, Statystyka. Elementy teorii i zadania, Wydawnictwo Akademii Ekonomicznej we Wrocławiu, Wrocław.

Panasiuk A. (red.), 2005, Marketing ustug turystycznych, PWN, Warszawa

Pawłowski Z.M., 1978, Ekonomia Polityczna, t. I, PWE, Warszawa.

Penc J., 2007, Nowoczesne kierowanie ludźmi. Wywieranie wpływu i współdziałanie $w$ organizacji, Difin, Warszawa.

Sobczyk M., 2016, Statystyka, PWN, Warszawa. 